\title{
Dr. Mary Edwards Walker: years ahead of her time.
}

Dre M. Irizarry, BS

Thomas Jefferson University

Nicole Salomone, AS

Thomas Jefferson University

Karen A. Chojnacki, MD

Thomas Jefferson University

Charles J. Yeo, MD

Thomas Jefferson University

Scott W. Cowan, MD

Thomas Jefferson University

Follow this and additional works at: https://jdc.jefferson.edu/gibbonsocietyprofiles

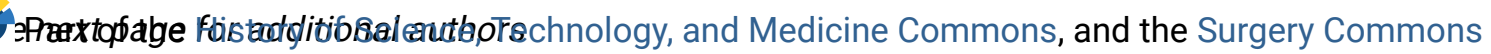
Let us know how access to this document benefits you

\section{Recommended Citation}

Irizarry, BS, Dre M.; Salomone, AS, Nicole; Chojnacki, MD, Karen A.; Yeo, MD, Charles J.; Cowan, MD, Scott W.; and Bogar, MD, Linda J., "Dr. Mary Edwards Walker: years ahead of her time." (2015). Department of Surgery Gibbon Society Historical Profiles. Paper 26.

https://jdc.jefferson.edu/gibbonsocietyprofiles/26

This Article is brought to you for free and open access by the Jefferson Digital Commons. The Jefferson Digital Commons is a service of Thomas Jefferson University's Center for Teaching and Learning (CTL). The Commons is a showcase for Jefferson books and journals, peer-reviewed scholarly publications, unique historical collections from the University archives, and teaching tools. The Jefferson Digital Commons allows researchers and interested readers anywhere in the world to learn about and keep up to date with Jefferson scholarship. This article has been accepted for inclusion in Department of Surgery Gibbon Society Historical Profiles by an authorized administrator of the Jefferson Digital Commons. For more information, please contact: JeffersonDigitalCommons@jefferson.edu. 


\section{Authors}

Dre M. Irizarry, BS; Nicole Salomone, AS; Karen A. Chojnacki, MD; Charles J. Yeo, MD; Scott W. Cowan, MD; and Linda J. Bogar, MD 


\title{
Surgical History Dr. Mary Edwards Walker: Years Ahead of Her Time
}

DRE M. IRIZARRY, B.S., NICOLE SALOMONE, A.S., KAREN A. CHOJNACKI, M.D., CHARLES J. YEO, M.D., SCOTT W. COWAN, M.D., LINDA J. BOGAR, M.D.

\author{
From the Department of Surgery, Thomas Jefferson University, Jefferson Medical College, Philadelphia, \\ Pennsylvania
}

W OMEN PHYSICIANS IN the United States were virtually nonexistent in the early to mid-1800s. Traditional medical schools still did not accept women, and few secretarian or eclectic medical schools were beginning to open their doors to female students. In 1849 at Geneva College, Elizabeth Blackwell became the first woman to achieve a medical degree in the United States. ${ }^{1}$ At the time of the Civil War, the few women who had managed to obtain medical degrees mainly served as nurses in the war, because society was not yet ready to accept the female physician. ${ }^{2}$ Dr. Mary Edwards Walker would help change the role of women physicians, becoming not only a valuable surgeon for the Union Army, but also a catalyst for the introduction and advancement of women in medicine.

Dr. Walker was born on November 26, 1832, in Oswego, New York, to Vesta Whitcomb and Alvah Walker, whose forward-thinking and abolitionist views shaped not only her childhood, but her entire life. Her parents firmly believed in education and equal rights for their five daughters. ${ }^{1,3}$ Dr. Walker would add to this liberal upbringing, reading about the first Women's Rights Convention as well as learning about Grahamite and Thomsonian views on temperance, diet, and herbal medicine. Among other influences, these would later have a profound impact on her life and medical practice. ${ }^{1}$

In 1855 , she became the second woman to obtain a medical degree in the United States, after three 13week semesters at Syracuse Medical College. ${ }^{1-3}$ In the years after graduation, Dr. Walker began writing and lecturing on medical topics, temperance, and dress reform. She was even elected one of nine vice-presidents of the National Dress Reform Association at their convention in $1860 .^{1}$

The outbreak of the Civil War in April 1861 and the First Battle of Bull Run in July of that same year sparked a great need for physicians. That Fall, wishing to contribute to the Union's cause, Dr. Walker wrote to the Surgeon General, Clement A. Finley, requesting an

Address correspondence and reprint requests to Scott W. Cowan, M.D., Department of Surgery, Thomas Jefferson University, 1100 Walnut Street, 5th Floor, Philadelphia, PA 19107. E-mail: Scott.Cowan@jefferson.edu. appointment as an assistant war surgeon to Dr. J. N. Green at Indiana Hospital. ${ }^{1,2}$ Despite Dr. Green's need for an assistant, Dr. Walker was turned away because she was a woman. Undeterred, she traveled to Indiana Hospital to serve without an appointment and without pay. ${ }^{1}$ During her time working at Indiana Hospital, Dr. Walker came to recognize the harsh approaches and largely unsuccessful medical practices of the time. Wishing to incorporate a more holistic approach to treatment, she obtained a second Doctor of Medicine degree in 1862 from Hygenio-Therapeutic College in New York. Her classes during that course of study mainly focused on hygiene and natural cures. ${ }^{1,3}$

Fortunately, her studies did not keep her from the battlefield for long, and in the final months of 1862, she volunteered on the front lines in Fredericksburg and Warrenton, Virginia, as a civilian surgeon. After the Union defeat at the Battle of Fredericksburg, more than 9000 Union soldiers had been wounded and needed medical care. Dr. Walker worked tirelessly to attend to these soldiers, receiving only rations and a tent for her service. ${ }^{1,3}$ Although not recognized by the army, her efforts were applauded locally as one newspaperman stated, "Her sex ought not to disqualify her for the performance of deeds of mercy to the suffering heroes of the Republic...she can amputate a limb with the skill of an old surgeon, and administer medicine equally as well." 1,2

Not satisfied with merely serving, Dr. Walker used her extensive experience with battlefield injuries and her recent studies in hygiene to try to change the current medical practice. While assisting General Burnside's Army, she observed that too many limbs were being amputated. She advocated for these soldiers, voicing which amputations she deemed unnecessary. ${ }^{1-3}$ This was indisputably controversial; however, Walker wrote, "I considered that I had a higher duty [to patients] than came under the head of medical etiquette." 2 The Walkers' neighbor in Oswego would years later notice the many soldiers that visited Dr. Walker later in life, thanking her for intervening and preventing the loss of their limbs. ${ }^{1}$

Although still not officially commissioned, Dr. Walker would continue to offer her assistance on the battlefield, frequently traveling into Confederate 


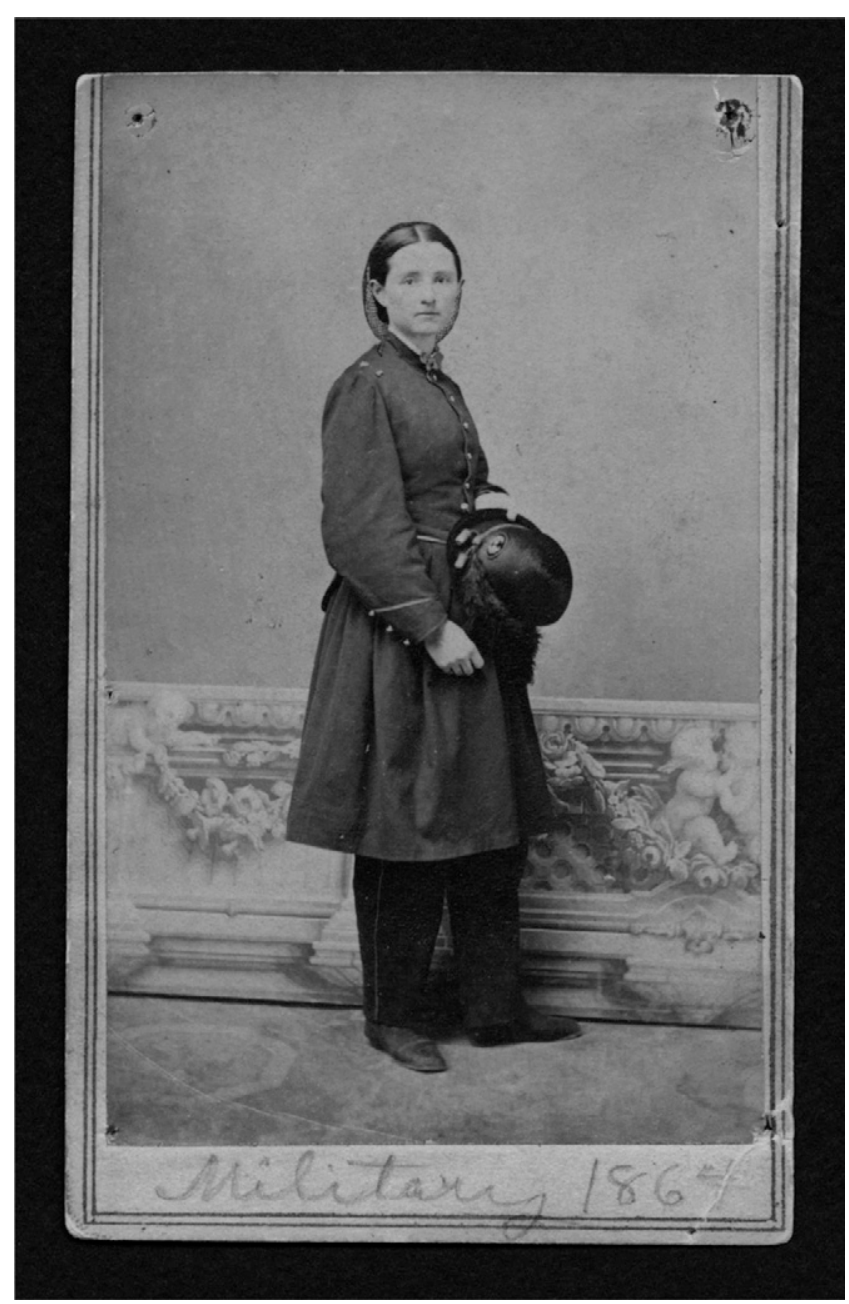

FIG. 1. Dr. Mary Edwards Walker in military uniform, January 1, 1864. Woman's Medical College of Pennsylvania: Photograph Collection. 1850-present (ACC-AHC1). Women Physicians. Legacy Center Archives, Drexel University College of Medicine. Available at: <http://xdl.drexelmed.edu/item.php?object_id $=2234 \&$ search_param $=$ name\&search_by $=$ Walker, $\% 20$ Mary $\% 20$ Edwards,$\%$ 201832-1919\&t $=$ womanmd $>$. Accessed May 15, 2012.

territory while donning her green surgeon's sash to care for wounded soldiers ${ }^{1}$ (Fig. 1). During one of these missions, Confederate soldiers captured Dr. Walker and held her for four months at Castle Thunder prison in Richmond, Virginia, as a prisoner of war. ${ }^{1-3}$ Not until two months after her release was Dr. Walker at last formally recognized as a surgeon on October 5, 1864. She was then hired as a contract surgeon for the Army and assigned to the Female Military Prison at Louisville. She would terminate her contract with the government less than one year later. ${ }^{1-3}$ Unfortunately, physical ailments that developed while she was a prisoner prevented her from practicing medicine after the war. Never tiring, she studied law, wrote two books, and continued to petition the government for equal rights. ${ }^{1}$

On November 11, 1865, Dr. Mary Edwards Walker became the first and only woman to be awarded the

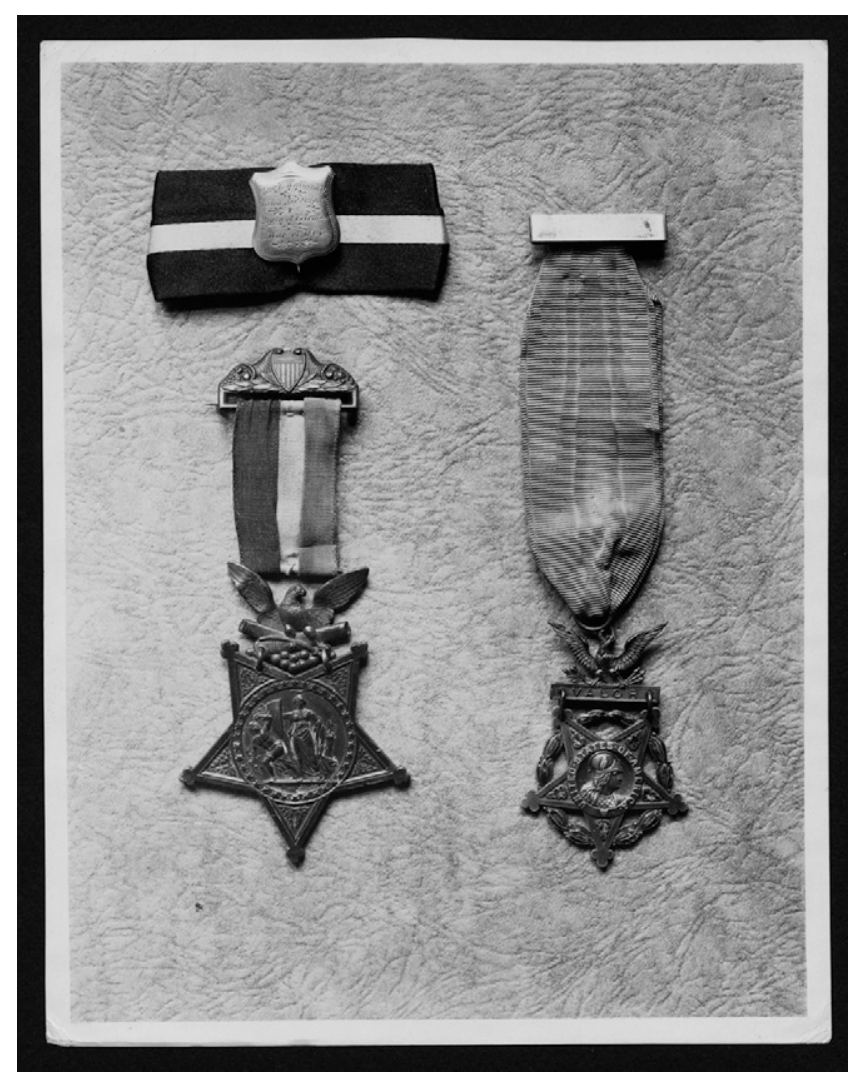

FIG. 2. Medals received by Dr. Mary Edwards Walker for her work as a surgeon in the Civil War. Woman's Medical College of Pennsylvania: Photograph Collection. 1850-present (ACC-AHC1). Women Physicians. Legacy Center Archives, Drexel University College of Medicine. Available at: <http://xdl.drexelmed.edu/ item.php?object_id $=2214 \&$ search_param $=$ name\&search_by $=$ Walker,\%20Mary\%20Edwards,\%201832-1919\&t = womanmd $>$. Accessed May 15, 2012.

Congressional Medal of Honor for her "patriotic zeal" and "valuable services to the government"1-3 (Fig. 2). This medal would be rescinded in 1917 along with 910 others as Congress passed new requirements that an individual had to be involved in "actual combat with an enemy." 2, 3 However, Dr. Walker refused to return her medal and wore it everyday until her death on February 21, 1919. ${ }^{1}$ Ironically the 19th Amendment, giving women the right to vote, would be ratified that next year.

On June 10, 1977, President Jimmy Carter restored Dr. Walker's Medal of Honor; to this day she is the only female recipient of this distinguished award. ${ }^{1-3}$ Although her life and medical career unfolded at a time when society was unwelcoming of female physicians, Dr. Walker is remembered as a skilled and dedicated Civil War surgeon and a pioneer for women's rights. Along with the work of other female physicians and nurses of the time, her work helped lay the foundation to change the face of medicine. As described by Dr. Walker in her personal notes, "My reason for my acts has been a strong conviction of that which I believed 
was right... I do not deserve credit for standing up to my principles, for I could not do otherwise."2

\section{REFERENCES}

1. Poynter L. Lida Poynter Collection on Dr. Mary E. Walker, circa 1850-1946. MS thesis, Drexel University College of Medicine,
Legacy Center: Archives and Special Collections on Women in Medicine and Homeopathy, Philadelphia, PA.

2. Graf M. A Woman of Honor: Dr. Mary E. Walker and the Civil War. Gettysburg, PA: Thomas Publications; 2001.

3. Goldsmith BZ. Dr. Mary Edwards Walker: Civil War Surgeon \& Medal of Honor Recipient. Edina, MN: ABDO Pub.; 2010. 